University of Nebraska - Lincoln

DigitalCommons@University of Nebraska - Lincoln

1998

\title{
CONTROLLED HYBRIDIZATION TECHNIQUE FOR SWITCHGRASS
}

Juan M. Martinez-Reyna

University of Nebraska-Lincoln

Kenneth P. Vogel

University of Nebraska-Lincoln, kvogel1@unl.edu

Follow this and additional works at: https://digitalcommons.unl.edu/usdaarsfacpub

Martinez-Reyna, Juan M. and Vogel, Kenneth P., "CONTROLLED HYBRIDIZATION TECHNIQUE FOR SWITCHGRASS" (1998). Publications from USDA-ARS / UNL Faculty. 1921.

https://digitalcommons.unl.edu/usdaarsfacpub/1921

This Article is brought to you for free and open access by the U.S. Department of Agriculture: Agricultural Research Service, Lincoln, Nebraska at DigitalCommons@University of Nebraska - Lincoln. It has been accepted for inclusion in Publications from USDA-ARS / UNL Faculty by an authorized administrator of DigitalCommons@University of Nebraska - Lincoln. 


\section{NOTES}

\section{CONTROLLED HYBRIDIZATION TECHNIQUE FOR SWITCHGRASS}

\author{
Juan M. Martínez-Reyna and Kenneth P. VogeL*
}

\begin{abstract}
Controlled hybridizations of plants are necessary for genetic studies, including those that use molecular markers. A hybridization technique for grass species such as switchgrass, Panicum virgatum L., with indurate floral bracts has not been previously reported. The objective of this study was to develop a technique for emasculating and hybridizing switchgrass. Emasculations were successful when the top of the stigmas could be seen through the translucent tips of the lemma and palea. Panicle branches containing 25 to 50 fertile florets were emasculated at this stage after removing excess panicle branches. Both sessile staminate florets and the fertile florets of a spikelet were emasculated because removal of the sessile floret damaged the upper fertile floret. Emasculations and hybridization were completed before natural pollen shed, which occurs after $1000 \mathrm{~h}$ in the greenhouse. Panicle branches with emasculated florets were covered with glassine bags. Anthers from florets of male parents at a similar stage of development were collected in petri dishes and shaken to induce pollen shed. Pollen in petri dishes was applied directly to stigmas of florets emasculated previously the same morning. The average percentage of crossability [(seed/floret emasculated and fertilized) 100] for crosses that produced seed was $27 \%$, with a range of 4 to $86 \%$. The procedure was successfully used to make controlled crosses in a greenhouse between plants of 'Summer', an upland tetraploid, and 'Kanlow', a lowland tetraploid switchgrass.
\end{abstract}

$S^{\mathrm{w}}$ ITCHGRASS is a native warm-season, cross-pollinated grass used in pastures and to reseed depleted rangelands (Moser and Vogel, 1995). The U.S. Department of Energy has identified switchgrass as a promising biomass fuel crop (Vogel, 1996) and research is in progress at several locations to develop switchgrass into a biomass fuel crop. Most cultivars have been developed by population improvement breeding methods where controlled hybridizations are not necessary (Moser and Vogel, 1995). However, controlled hybridizations are necessary for genetic studies, including those that use molecular markers. A general technique for hand emasculation of small grass florets without indurate or hardened floral bracts has been described by Burson (1980). Richarson (1958) also described a procedure for use

J.M. Martínez, Agronomy Dep., Univ. of Nebraska, Lincoln, NE; K.P. Vogel, USDA-ARS, 344 Keim Hall, Univ. of Nebraska, P.O. Box 830937, Lincoln, NE 68583-0937, and Center for Grassland Studies, Univ. of Nebraska. The reported research is from the graduate research of the senior author at the Univ. of Nebraska in partial fulfillment of the requirements for a Ph.D. degree. The research was funded in part by the U.S. Dep. of Energy's Biomass Fuels program via the Oak Ridge National Laboratory Contract No. DE-A105-900R21954 USDA-ARS, and the Univ. of Nebraska. Journal series no. 11964, Nebraska Agric. Exp. Stn. Received 24 July 1997. *Corresponding author (agro012@unlvm.unl.edu).

Published in Crop Sci. 38:876-878 (1998). with species of tribe Andropogoneae, and this technique can be used for species with similar floral morphology. Switchgrass, like most forage grasses, has small florets that makes emasculations and controlled crosses difficult. The florets of switchgrass and other Panicum species have an indurate or hardened lemma and palea that tightly enclose the stamens and pistil, and later the caryopsis, as protective bracts (Hitchcock, 1951) and hence require specific emasculation procedures. A hybridization technique for switchgrass has not been described. The purpose of this report is to describe an emasculation and crossing procedure that can be used to make controlled crosses of switchgrass.

\section{Floral Morphology and Pollination Characteristics}

The inflorescence of switchgrass is a diffuse panicle, 15 to $55 \mathrm{~cm}$ long, with spikelets at the end of the long branches. Spikelets are two flowered, with the first floret sterile or staminate and the second one fertile (Hitchcock, 1951) (Fig. 1). An individual panicle will be at anthesis for up to $12 \mathrm{~d}$ and the peak pollen shedding periods in fields at Lincoln, NE, were from 1000 to 1200 or from 1200 to $1700 \mathrm{~h}$ depending on environmental conditions (Jones and Newell, 1946). Switchgrass flowers basipetally. It is largely self-incompatible (Talbert, 1983) but some plants will set a small quantity of selfed seed when bagged (L.C. Newell, 1936. Annual Report, Grass Improvement Investigations, USDA and the Nebraska AES, Lincoln, NE).

\section{Hybridization Technique}

\section{Plant Material}

Plants of Kanlow, a lowland tetraploid population (' $L$ ' cytotype), and Summer, an upland tetraploid (' $U$ ' cytotype) (Hultquist et al., 1996) were used in this study. Plants were grown in the greenhouse with an 18 -h photoperiod and a mean temperature of $28^{\circ} \mathrm{C}$. Fluorescent lights were used to extend the day length. Since flowering times between the cultivars were not totally synchronized, late inflorescences of Summer were crossed with early inflorescences of Kanlow.

\section{Emasculation}

Emasculation and pollination were completed at $1000 \mathrm{~h}$, before natural pollen shed occurs in the greenhouse. Branches from the same node of a panicle having 25 to 50 florets at a similar stage of development before anthesis were selected for emasculation. The development stage of florets at which emasculation was most easily accomplished was when the lodicules at the base of the ovary are swollen (Fig. 2). At this stage, the lemma and palea were easily pulled apart, and the anthers were removed without damaging the stigma. Because the lod- 


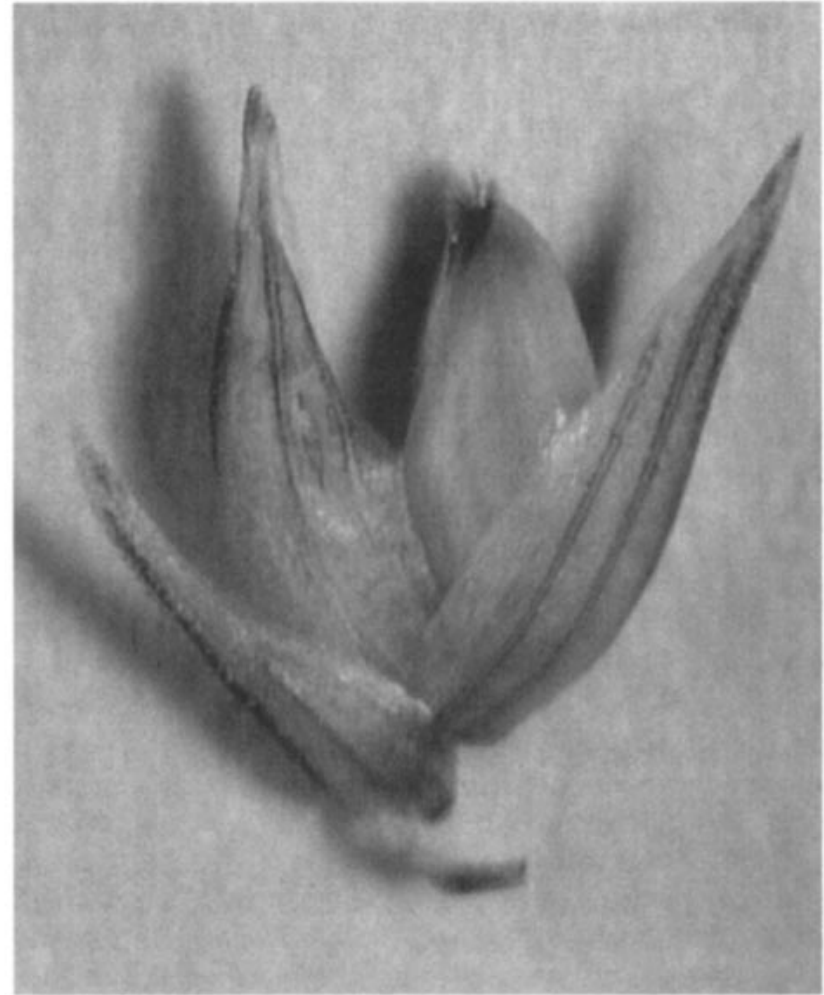

Fig. 1. Spikelet of switchgrass with lower staminate floret and upper perfect floret. Upper floret is beginning to open as indicated by tip of purple stigma above the lemma. Spikelet is $4.5 \mathrm{~mm}$ in length.

icules are not visible, a useful indicator of this stage was the purple color of the stigma which could be seen through the translucent tips of the lemma and palea (Fig. 3). Although, the most common stigma colors in switchgrass are purple and light purple, white also is found. For plants with white stigmas, the size and plumpness of the florets was used to detect the stage for making emasculations. Only florets that had reached the swollen lodicule stage were left intact to be emasculated. Spikelets whose florets had already extruded anthers and those that were in an earlier stage of development were removed with scissors. In some instances, it was necessary to thin panicle branches to simplify emasculation and pollination.

Anthesis of the lower, staminate florets occurred 2 or $3 \mathrm{~d}$ later in our greenhouse conditions than anthesis of the upper floret. The lower florets must be emasculated or removed to avoid possible self-pollination. Richarson (1958) indicated that the sterile floret in Andropogoneae species must be removed, which is easily done in that tribe because the sterile floret is pedicellate, but in switchgrass we found that removing the sessile sterile floret damaged the fertile floret.

We began emasculation at the upper part of a branch of the panicle and emasculated one branch at a time. The sterile floret was emasculated first. The spikelet was held between the thumb nail and the index finger with limited pressure (Fig. 4). If excessive pressure is applied the spikelet may disarticulate above the glumes. We found it is easier to detect the applied pressure if the thumb nail extends beyond the tip of the thumb.

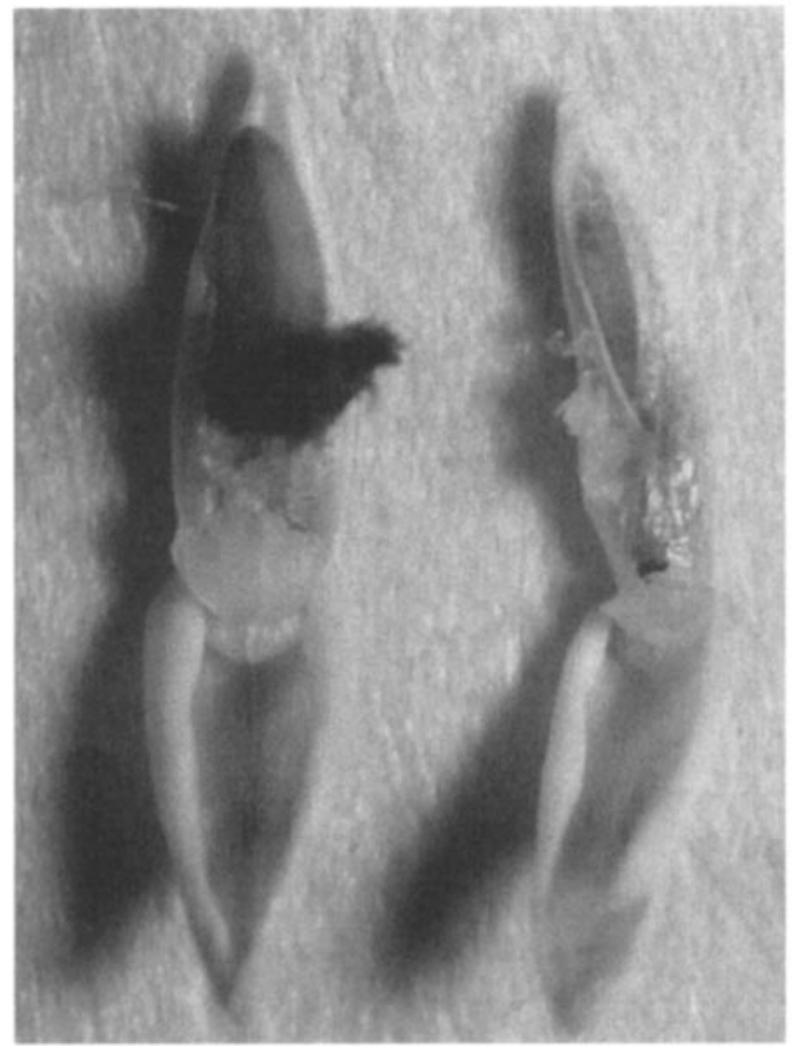

Fig. 2. Dissected switchgrass floret at left has swollen lodicules and is ready to open; foret at right has smaller lodicules and is not ready to open. Magnification is $27 \times$.

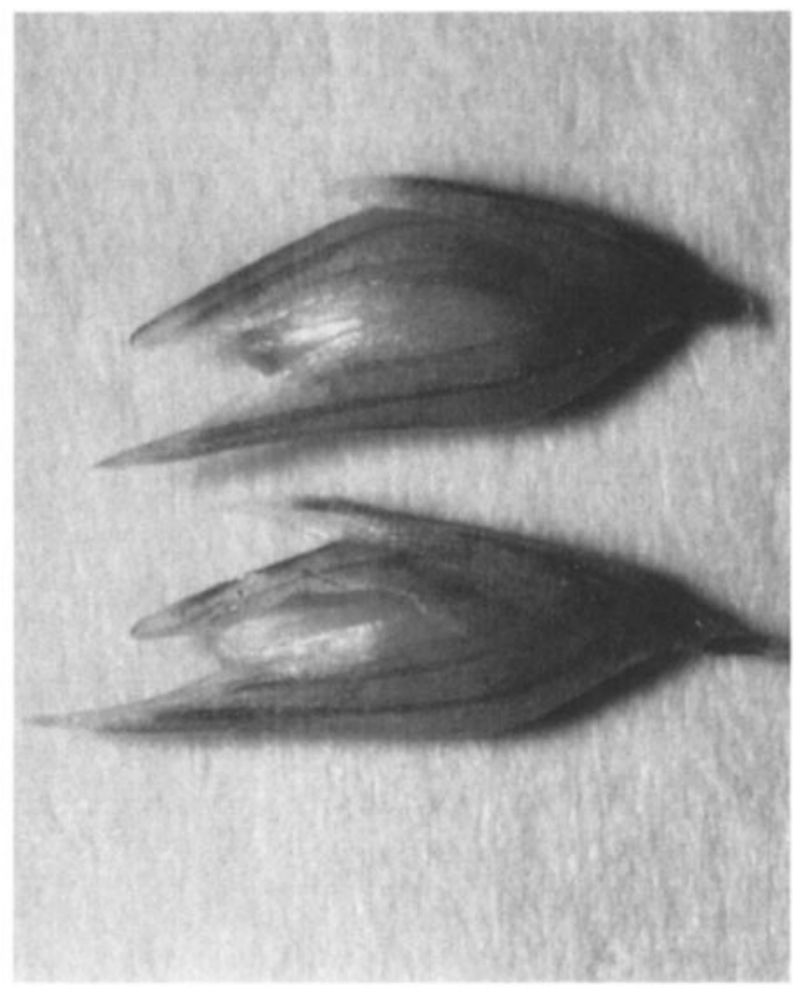

Fig. 3. Switchgrass florets at the proper stage for emasculation. Lower floret has a white stigma and upper floret has a purple stigma that is partially visible through the translucent tips of the lemma and palea. Magnification is $13 \times$. 


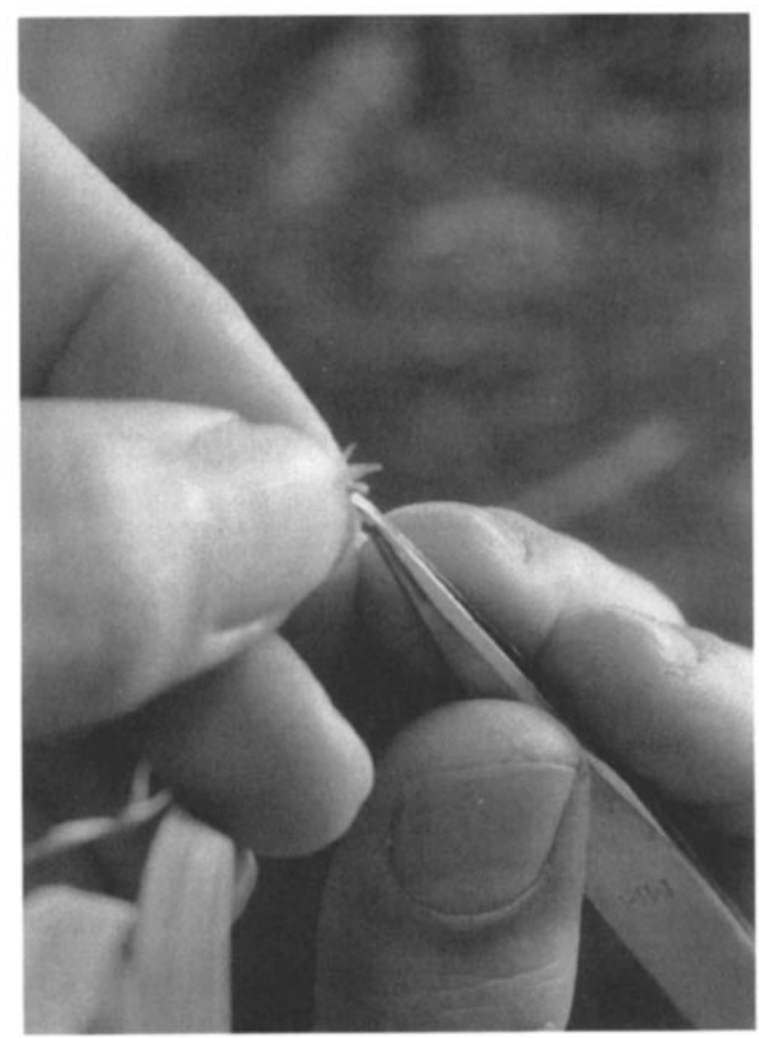

Fig. 4. Emasculating switchgrass florets with forceps.

After the three anthers of the sterile floret were extracted, the spikelet was turned $180^{\circ}$ and the upper floret was emasculated. To open a floret, the lemma was pulled down from the tip of the floret. Occasionally the points of the tweezers had to be inserted between the tips of the lemma and palea to separate them slightly before the lemma could be pulled down. Once the lemma and palea were pulled apart, the anthers were exposed and removed with tweezers. However, sometimes the anthers were not exposed, and to dislodge them the palea had to be pushed gently at the bottom part of the floret. To avoid potential pollen contamination, the three anthers of each floret were counted as they were removed. Magnifying glasses were worn when making emasculations. After all the florets of the selected branches were emasculated, the emasculated panicle branch was enclosed with a $5 \times 20 \mathrm{~cm}$ glassine bag. The bag was tied with twist ties to bamboo stakes for support.

\section{Pollination}

Anthesis and receptivity of the stigmas occurred on the same day. Handling the florets during emasculation warmed the florets and stigmas reached the feathery appearance that characterized the receptive stage a few minutes after emasculation. Because peak pollen shedding occurred later in the morning in switchgrass, mature anthers from the male parent were collected in a small petri dish and shaken to promote pollen shed. Pollen collected in the petri dishes was used to pollinate florets emasculated earlier in the morning and before the natural shedding of the pollen began $(1130-1200 \mathrm{~h}$ ) in the greenhouse. This practice prevented fertilization by random pollen in the greenhouse. To facilitate pollination each stigma was dipped individually into the pollen collected in the petri dish.

\section{Hybridization Efficiency}

Sixty-six crosses were made in which 18 Kanlow (lowland) and 10 Summer (upland) plants were used. A total of 2293 florets were emasculated and fertilized. Fortyone lowland (female) by upland (male) crosses were made of which 27 produced seed. The average percentage of crossability [(seed/floret emasculated and fertilized) 100] for the crosses that produced seed was $27 \%$ with a range of 4 to $86 \%$. Twenty-five upland (female) by lowland (male) crosses were made of which 14 produced seed. The crossability percentage for the crosses that produced seed was $12 \%$ with a range of 2 to $26 \%$. The seeds germinated and seedlings have been produced demonstrating that the crosses were successful. The parents and progeny of the crosses were screened for several morphological characteristics. Pubescence at the upper base of the leaf blade adjacent to the ligule was found to be a useful marker to identify hybrids. Plants of Summer have abundant pilose pubescence in this region while plants of Kanlow have none. The hybrid plants were intermediate in pubescence in comparison to the parents. This report documents the first successful controlled crosses between upland and lowland switchgrass validating the effectiveness of the procedure. We suspect the range of crossability found in these crosses is due mainly to the effect of a pre-fertilization incompatibility system present in switchgrass, and we are investigating this possibility. If a pre-fertilization incompatiblity system exists in switchgrass, the hybridization efficiency of this technique will depend on the genetic constitution of the plants being intermated.

\section{References}

Burson, B.L. 1980. Warm-season grasses. p. 695-708. In W.R. Fehr and H.H. Hadley (ed.) Hybridization of crop plants. ASA and CSSA, Madison, WI.

Hitchcock, A.S. 1951. Manual of grasses of the United States. Revised by Agnes Chase. Misc. Publ. 200. 2nd ed. USDA, Washington, DC.

Hultquist, S.J., K.P. Vogel, D.J. Lee, K. Arumuganathan, and S. Kaeppler. 1996. Chloroplast DNA and nuclear DNA content variations among cultivars of switchgrass, Panicum virgatum L. Crop Sci. 36:1049-1052.

Jones, M.D., and L.C. Newell. 1946. Pollination cycles and pollen dispersal in relation to grass improvement. Nebraska Agric. Exp. Stn. Res. Bull. 148.

Moser, L.E., and K.P. Vogel. 1995. Switchgrass, big bluestem, and indiangrass. p. 409-420. In R.F Barnes et al. (ed.) Forages. Vol. I: An introduction to grassland agriculture. 5th ed. Iowa State Univ. Press., Ames, IA.

Richarson, W.L. 1958. A technique of emasculating small grass florets. Indian J. Genetic Plant Breed. 18:69-73.

Talbert, L.E., D.H. Timothy, J.C. Burns, J.O. Rawlings, and R.H. Moll. 1983. Estimates of genetic parameters in switchgrass. Crop Sci. 23:725-728.

Vogel, K.P. 1996. Energy production from forage for American agriculture - Back to the future. J. Soil Water Conserv. 51:137-139. 